\title{
Effects of Management Accounting Practices on Financial Performance of Small and Medium Enterprises in Gusau Metropolis of Zamfara State, Nigeria
}

\author{
Onumoh Ahmed Yahaya \\ School of Business and Entrepreneurship Education \\ Federal College of Education (Technical) Gusau, Zamfara State, Nigeria
}

\begin{abstract}
This study focused on the effects of management accounting practices on financial performance of Small and Medium Enterprises (SMEs) in Gusau Metropolis of Zamfara state. The study considered some SMEs in Gusau metropolis of Zamfara state. Survey and correlation research design was used for the study. Twenty (20) SMEs were selected and in which each SME five (5) top management staff were also selected as they have adequate knowledge to response to the questionnaire of this study. Primary data was employed in gathering data for the study through structured questionnaire. The data collected were analyzed through SPSS 16.0. Financial performance serve as dependent variable while costing, budgeting and performance evaluation serves as independent variables. The result of the study shows that the costing, budgeting and performance evaluation has a positive and significant influence on financial performance of SMEs in Gusau metropolis of Zamfara state. The study recommends that the owners and managers of Small and Medium Enterprises in Gusau metropolis of Zamfara state should adopt the use of costing practice in their operations as this will help them to know the product unit cost and it will assist them in fixing unit price of their product at a profitable rate.
\end{abstract}

Keywords: Budgeting, Costing, Financial Performance, Performance Evaluation.

DOI: $10.7176 /$ RJFA/10-11-03

Publication date:June $30^{\text {th }} 2019$

\section{Introduction}

Management accounting practice assists an organization to survive in the competitive, ever-changing world, because it provides an important competitive advantage for an organization that guides managerial action, motivates behaviours, supports and crafts the cultural values needed to achieve an organization's strategic goals. Management accounting is concerned mainly with the internal needs of management. It is oriented toward assessment of performance and development of estimates of the future as divergent to traditional financial accounting which stresses historical data related to such legal financial matters as ownership, investment, taxation, credit granting, regulation, and the building of foundations for dependable and conventional external reporting, "in harmony with generally accepted accounting principles." Flexibility is an indispensable characteristic of management accounting since it assumes that careful attention has been given to determine the significant needs of management, many of which cannot be exactly identified in advance (Parker, 2002).

There are many different means to measure financial, but all measures should be taken in aggregation. Some of the pointers of financial performance are liquidity ratios, return on equity, leverage ratios, profitability ratios and market value ratios. Carreta and Farina (2010) argued that use of financial performance could still be vindicated on the grounds that it reveals what managers really consider to be financial performance and, even if this is a mixture of various indicators like productivity, accounting profits and cash flow. Financial performance is determined by the following pointers; value added; sales, budget; expenditure and stock market indicators and autonomy. Proxies for the financial performance also contain the accounting measure of performance; return on asset (ROA) and return on equity (ROE).

Uyar (2010) documents that the perceived importance of cost accounting is motivated by increasing costs and competition, decreasing profitability, and economic crises. The author also emphasized that while companies still recognise traditional management accounting tools as still important, new management accounting practices such as transfer pricing and strategic planning are perceived less significant than traditional ones. The study also establish that the most important three management accounting practices are planning and control, planning and control, budgeting, and cost-volume-profit analysis.

Management accounting as a research study has not been fully explored in Nigeria. A few studies exist on the same mainly as theses and dissertations in various universities in Nigeria (for instance Arithi, 2001; and Wairegi, 2011). Therefore, it can be decided that the effects of management accounting practices on financial performance in Nigeria is not well recognized just as much as in other developing countries as had suggested Li and $\mathrm{Yu}(2002)$.

Management accounting provides the best opportunity for firms to compete in the market in order to offer best quality products and services at reasonable prices to consumers. Most of the existing study literature on 
accounting in Nigeria manufacturing companies tends to be more unfair toward the arm of financial accounting, information technology adoption as well as investigation in credit accessibility for manufacturing companies, more so only remote exists in regard to effects of management accounting practices on financial performance of manufacturing companies in Nigeria (Wairegi, 2011) and (Makau, Wawire, \& Ofafa, 2013), notwithstanding this previous research studies being vital, lack of management accounting practices for decision making and lack of technical skills are as much hindrances to developing manufacturing companies as is the lack of ability to access credit (Mbogo, 2011). This study thus sought to institute the effects of management accounting practices on financial performance of Small and Medium Enterprises (SMEs).

The general objective of this study was to investigate the effects of management accounting practices on financial performance of manufacturing companies in Nigeria. The specific objectives are:

I. To establish the effect of costing practice on financial performance of Small and Medium Enterprises in Gusau metropolis of Zamfara state.

II. To assess the effect of budgeting practice on financial performance of Small and Medium Enterprises in Gusau metropolis of Zamfara state.

III. To examine the effect of performance evaluation practice on financial performance of Small and Medium Enterprises in Gusau metropolis of Zamfara state.

\section{Research hypotheses}

I. Costing practice has no significant effect on financial performance of Small and Medium Enterprises in Gusau metropolis of Zamfara state.

II. Budgeting practice has no significant effect on financial performance of Small and Medium Enterprises in Gusau metropolis of Zamfara state.

III. Performance evaluation practice has no significant effect on financial performance of Small and Medium Enterprises in Gusau metropolis of Zamfara state.

\section{Concept of management accounting}

The process of identification, measurement, accumulation, analysis, preparation, interpretation, and communication of financial information used by management to plan, evaluate, and control within an organization and to assure appropriate use of and accountability for its resources (Smith, 2009). According to Ndwiga (2011) management accounting practices are connected with providing management solutions for the internal management purposes. Epstein and Lee, (2008) as well as Nuhu, Baird and Appuhami, (2016) are of the view that management accounting practices are organizational information systems that offer an organization with pertinent information to add value to its customers and organisations. Management accounting practices enables effective decisions and assist organisations in encouraging intended behaviours (Abdel-Kader \& Luther, 2006). Management accounting practices can comprises Cost, budgeting, performance evaluation, information for decision-making and strategic analyses, among many others (Gichaaga, 2013).

Costing: - Study reveals that the information on product costs generated by costing systems has a wide number of uses. These uses include, for example, pricing decisions; cost control, (Van Triest \& Elshahat, 2007); an evaluation of production processes; and transfer pricing (Barton \& Gordon, 2008). However research has focused on which costing systems used by firms. The following discussion appraisals signal on the level of uptake of costing systems from previous studies.

The two key costing methods accepted were absorption costing and direct (variable) costing. Absorption costing system is general preferred internationally. For example Parker (2002) perceived that 58 per cent of U.K firms often used absorption costing and Uyar (2010) establish that around half of German firms applied this technique. Meanwhile, Shields, Arithi (2001), who made a comparison between Japan and the U.S reported that Japanese companies indicated about 59 to 67 per cent usage against a slightly higher uptake at 70 to 75 per cent by U.S companies. More recently, Wairegi (2011) found that 90 per cent of Polish firms adopted this technique. In developing countries uptake rates are similar. For example in India, Joshi (2001) reported half of Indian firms adopted this technique and Epstein and Lee (2008) revealed 66 per cent of Chinese foreign-based companies applied this technique.

Budgeting: - Research establish that budgeting is alleged as an important control system in almost all organizations (Mbogo, 2008). Previous research reveals that the main purposes of budgeting are planning the future financial position; planning future performance; planning future day to day operations; planning future cash flows; and controlling costs (Sulaiman, Ahmad and Alwi, 2004; Abdel-Kader et al, 2006). The use of specific types of budgeting technique such as flexible budgets, rolling budgets, ZBB and operational budgets has been researched. Ahmad, Sulaiman and Alwi (2003) found that the uptake of flexible budgets in Malaysia is higher compared to those in UK and New Zealand. With respect to control aspects of budgeting, Parker (2002) found that majority of UK industrial companies were using both standard costing and budgeting system in their firms.

Performance evaluation: - Epstein and Lee (2008) noted that performance evaluation was an important 
function of management accounting. Performance evaluation provides information for managers to support the achievement of their organization's strategic objectives (Li \& Yu, 2002). Mbogo (2011) argued that in recent years organizations have sought to develop more comprehensive performance measurement systems (PMS) to provide managers and employees with information to assist in managing their operations.

Decision support system: - In previous research, Wu, Boateng and Drury (2007) hold that effective decision making is the most important key factor in today's rapid and changing competitive environment. The decision support analysis can be separated into short term and long term analysis. Abdel-Kader and Luther (2006) contended that for regular or short-term decisions management accountants can use product profitability analysis, costvolume-profit (CVP) analysis, stock control models, and customer profitability analysis. In respect of longer-term capital investment decisions management accountants can produce and evaluate payback periods and accounting rates of return as well as complex signals based on discounted cash flow. Capital budgeting techniques capture both non-discounted and discounted approaches Ndwiga (2011) argued that the superiority of internal rate of return (IRR) and net present value (NPV) analysis has been repeatedly demonstrated under conditions of certainty. Under uncertainty, the techniques used are sensitivity analysis, increased required rates of return, game theory, and Monte Carlo computer based simulation.

\section{Concept of financial performance}

Financial performance can be described as a subjective measure of how well a firm can use assets from its primary mode of business and produce revenues (Mills, 2008). This term is also used as a broad measure of a firm's overall financial wellbeing over a given period of time, and can be used to relate similar firms across the similar industry or to compare industries in aggregation. The performance measurement concept documents that employees can increase the value of the firm by; growing the size of a firm's future cash flows, by fast-tracking the receipt of those cash flows, or by making them less risky (Carreta \& Farina, 2010).

Wairegi (2011) argue the opposite, that financial indicators based on accounting information are sufficient in order to determine the value for shareholders. A manufacturing firm financial performance is directly affected by its market position. Smith (2009) argues that both can influence the profitability of a company one time. If a high turnover signifies better use of assets owned by the company and therefore better effectiveness, a higher profit margin signifies that the entity has considerable market power.

Risk and growth are two other important elements influencing manufacturing firms' financial performance. However, as market value is conditioned by the company's results, the level of risk exposure can cause variations in its market value. Economic growth is another element that helps to attain a better position on the financial markets, because market value also takes into consideration expected future profits (Parker, 2002). The size of the company can have a positive result on financial performance because larger firms can use this to get some financial benefits in business relations. Large companies have easier access to the most significant factors of production, including human resources. Also, large organizations often get inexpensive funding. In the classical theory, capital structure is irrelevant for measuring company performance, considering that in a perfectly competitive world performance is influenced only by real factors (Mills, 2008).

\section{Management accounting in SMEs}

Despite the economic and social importance of SMEs, there is a lack of research initiatives studying the provision for management accounting information and use of management accounting techniques by SMEs (Mbogo, 2011). Makau et al (2013) suggests that this may be because research into MAPs is predicated in the belief that the discipline of management accounting is best served by studying (and so finally facilitating the emulation of) the most innovative and successful practitioners. This position inevitably skews research towards larger entities. As Uyar (2010) observed, this belief has led to empirical management accounting research designed to investigate technical innovation and development being concentrated on larger enterprises to the exclusion of smaller firms where the know-how and capacity to innovate in management accounting is less likely to exist. Therefore this situation leaves a significant gap into the study of MAPs in SMEs. However, limited examples of research into MAPs in SMEs in developed countries exist. For example, Gichaaga (2013) found that small businesses generally reported using more simplistic techniques, and the use of techniques such as ABC, sensitivity analysis, market research and advanced quantitative techniques tended to be limited to the larger business units.

\section{Empirical studies}

$\mathrm{Wu}$ et al. (2007) conducted a survey that asked management accountants, in New Zealand manufacturing businesses, to indicate the techniques adopted in their business. While many studies have focused on particular techniques such as $\mathrm{ABC}$ or target costing, Wu et al. provided a questionnaire that included a massive array of management accounting techniques to provide a complete set of response alternatives. Respondents were requested to rank management techniques on a five point scale "from most used to least used". A judgment sampling method was chosen to attain a response rate of $25 \%$ that provided 165 completed questionnaires. Traditional management 
accounting techniques, such as direct costing, full costing, and standard costing were establish to be often used than advanced management accounting techniques, such as strategic management accounting. The study by Suleiman et al. (2004) is mostly consistent with the lack of acceptance of advanced management accounting techniques as stated by the Mbogo (2011) and Cassel (2003) studies, but inconsistent with respect to individual techniques. It was establish that firms in Australia adopted $\mathrm{ABC}$, and cost of quality techniques and also that big firm were more likely to use contemporary accounting techniques

Nuhu et al. (2016) in their investigation of cost management practices in India considered the responses furnished by 53 Chief finance Offices (CFOs) in Indian corporations. The purpose of their study was to capture the development in cost management practices such as accounting for applications of budgetary control and standard costing, overheads in corporate India. The survey questionnaire also meant to verify any important difference in management inspiration for the implementation and use of standard costing as a control tool between firms using traditional costing systems and firms using activities based cost management (ABCM). The study recognized that the firms are successful in seizing accurate cost and profit information from their ABC cost systems for value chain and supply chain analysis. The results document that the firms have better awareness for benchmarking and budgeting with $\mathrm{ABC}$ cost system yet the reliability in their priority of budget goals is lacking unlike the firms who are using traditional costing systems.

Abdel-Kader and Luther (2006) investigate management accounting practices (MAPs) in the food and drinks industry in the U.S.A. in order to comprehend the level of MAP's sophistication and the factors that influence implementation of MAPs in this industry. The research methodology adopted in this study was a survey questionnaire sent to 651 executives of the industry. In total, 246 usable completed questionnaires were received and analysed. Respondents were asked to indicate the frequency of use of 39 management accounting practices (MAPs) by means of a Likert scale (1 indicating never to 5 indicating very often). They were also asked to assess the significance of each technique/practice by rating these as range from 'not important to important. The study establish that as companies moved into a more unclear environment, the sophistication level of management accounting practices increased. Likewise, as their relative power to customers' diminished, companies moved up the stages of evolution. Analysis of the management accounting practices used documented that the management accounting systems employed in many manufacturing companies were not particularly sophisticated. Taking the industry as a whole, there was slight evidence of management accounting directly associated with 'value creation'.

Makau et al. (2013) conducted an empirical study to examine the application of contemporary management accounting techniques in Indian industry through a survey of 540 member companies. Sixty three companies retorted which constituted the sample; a response rate of about 14\%. A five point Likert scale was used. The emphasis of the study was to discover evidence on how broadly traditional and contemporary management accounting practices were adopted by Indian industry. The surveys revealed that improvement of overall profitability and cost reduction were the inspiring factors for using management accounting in Indian companies. The researcher establish a positive association between the adoption of ABC and company characteristics (e.g. degree of customization, business size, pressure of competition, and proportion of overhead to total cost). However, none of these differences was document to be significant at $10 \%$ level.

Epstein and Lee (2008) examined the usage of management accounting practices in manufacturing firms in Malaysia. They also conducted a studied on the relationship between product variety, complexity of production process, level of competition, company size, overhead expenses and usage of advanced management accounting practices. Management accountants in 600 manufacturing firms were randomly selected from the 2004/2005 Federation of Malaysian Manufacturers Directory. A total of 80 usable responses were received, that represented a response rate of $15 \%$. In the study, the measures for traditional management accounting techniques (TMAT) and advanced management accounting techniques (AMAT) were adopted from Li and Yu (2002). The TMAT were represented by four techniques: full standard costing, costing, job order costing and process costing. The AMAT comprised thirteen techniques: Activity-Based Costing, Activity-Based Management, Value Added Accounting, Target Costing, Kaizen Costing, Cost of Quality, Economic Value Added, Target Cost Planning, Cost Modeling, and Life Cycle Costing, Strategic Management Accounting, Throughput Accounting and Back Flush Costing.

Salawu (2012) conducted a survey of Activity Based Costing Adoption Among Manufacturing Companies in Nigeria. The study document that inability of the traditional cost systems to provide relevant cost was the most highly ranked reason in their decision to adopt $\mathrm{ABC}$. Traditional methods of allocating overhead were therefore believed to be lacking in terms of improving worldwide competitiveness. Also, $70 \%$ of the respondents have adopted $\mathrm{ABC}$ due to increased ranges of products, competition and increased overhead. Familiarity with and adoption of $\mathrm{ABC}$ was document to be across the manufacturing, more than half of the sample are familiar with it. The $45 \%$ of respondents who have not adopted $\mathrm{ABC}$ cited the cost and complexity involved with implementation as the main reason in non-adoption. Therefore, cost of implementing $\mathrm{ABC}$ was huge which hamper the small scale manufacturing from adopting it. This result may reflect the fact that larger firms are more likely to have the mixed of products or services that makes the use of $\mathrm{ABC}$ advantages. Consequently, the study recommends that the companies who have not approved $\mathrm{ABC}$ because of its high cost of implementation should endeavour to consider 
its adoption because in the long run the benefits arise from it will outweigh its cost. It aids to identify inefficient products, departments and activities and helps to allocate more resources on profitable products. In conclusion, the senior management should also give their greatest support to the implementation and success of ABC.

Wairegi (2011) study investigated the management accounting practices, and management accounting techniques used by quoted companies in Kenya and the type of management accounting reports produced and the frequency of their production. The study also explored the management accounting techniques used by these companies and the extent of their utilization. The basic premises of the study were that the success of any business in a competitive environment depends to a large extent, on the availability of timely and quality information for decision making. The study used census study of all the publicly quoted companies in Kenya. Data was collected using a semi-structured questionnaire and analysed using tables, averages, proportions, and percentages. The findings however document that there was no significant relationship between type and process of budgeting and the ownership and sector of the company. The most significant purpose of management accounting reports was planning and control.

\section{Methodology}

Survey and correlation research design was used for the study. The population of this study consist of all 324 registered SMEs in Gusau Local Government Area, Zamfara state. Simple random sampling technique was used to select the sample size of twenty (20) SMEs. The questionnaires were self-administered to collect data from respondents. The questionnaire was anchored on 5 point Likert scale ranging from " 5 " very often to " 1 " never. Multiple regressions were adopted as a technique of data analysis to examine the study. Furthermore, regression analysis was employed because the study wants to determine the causes and effect of the relationship of each variable via SPSS 16.0. The model specification to assess the effect of management accounting practice on financial performance of SMEs in Zamfara State is stated below:

$\mathrm{fp}=\alpha_{0}+\alpha_{1} \cos \mathrm{t}+\alpha_{2} \mathrm{bud}+\alpha_{3} \mathrm{pe}+\varepsilon$

Where

$\alpha_{0}=$ Intercept of the regression line

$\varepsilon=$ represent the error term.

cost $=$ costing practice

bud $=$ budget practice

pe $=$ performance evaluation practice

Data analysis and discussion

Table 1: Correlation Matrix

\begin{tabular}{lllll}
\hline & Financial performance & Costing & Budgeting & $\begin{array}{c}\text { Performance } \\
\text { Evaluation }\end{array}$ \\
\hline Financial performance & 1 & & & \\
Costing & $.887^{* *}$ & 1 & & \\
Budgeting & $.731^{* *}$ & $.768^{* *}$ & 1 & \\
Performance Evaluation & $.644^{* *}$ & $.654^{* *}$ & $.546^{* *}$ & 1 \\
\hline
\end{tabular}

**. Correlation is significant at the 0.01 level (2-tailed)

Source: SPSS 16.1 Result Output, 2018

From table 1, the correlation analysis indicates that there is positive and significant relationship between financial performance and the independent variable (costing, budgeting and performance evaluation) but there is no strong correlation between explanatory variables.

Table 2: Summary of regression result

\begin{tabular}{llll}
\hline Variables & Coefficient & $\mathrm{t}$ value & $\mathrm{p}$ value \\
\hline Constant & -1.049 & -3.130 & 0.033 \\
Costing practice & .596 & 4.270 & 0.000 \\
Budgeting practice & .383 & 11.253 & 0.000 \\
Performance evaluation Practice & .466 & 8.655 & 0.001 \\
$\mathrm{R}$ & & & .867 \\
$\mathrm{R}^{2}$ & & & .798 \\
Adjusted R & & & .836 \\
F Statistic & & & 121.41 \\
F-sig & & & 0.000 \\
Durbin-Watson & & & 1.843 \\
\hline
\end{tabular}

Source: SPSS 16.1 Result Output, 2018

From table 2, the cumulative correlation between dependent variable and all the independent variables was 0.798 indicating that the relationship between dependent variable and independent variables used in this study was 
$79.8 \%$ which is positively, strongly and statistically significant. The cumulative $\mathrm{R}^{2}(0.936)$ which is the multiple coefficient of determination gives the proportion or percentage of the total variation in the dependent variable explained by the independent variable jointly. Hence, it signifies that $83.6 \%$ of the total variation in financial performance of SMEs in Gusau caused by costing practice, budgeting practice and performance evaluation. This indicates that the model is fit and the explanatory variables are properly selected, combined and used. This can be confirmed by 1.843 and the valve of F-statistics of 121.41 significant at $1 \%$ level of significance.

\section{Test of null hypotheses}

This section test the hypotheses formulated.

Null Hypothesis one: Costing practice has no significant effect on financial performance of Small and Medium Enterprises in Gusau metropolis of Zamfara state.

From table 2 it shows that costing practice has positive significant effect on SMEs financial performance in Gusau at $1 \%$ level of significant. The researcher therefore not accepting the null hypothesis which says that level of costing practice has no significant effect on SMEs financial performance in Gusau and accept the alternative hypothesis.

Null Hypothesis two: Budgeting practice has no significant effect on financial performance of Small and Medium Enterprises in Gusau metropolis of Zamfara state

From table 2 it shows that budgeting practice by SMEs in Gusau has positive significant effect on their financial performance at $1 \%$ level of significant. The researcher therefore not accepting the null hypothesis which says that budgeting practice has no significant effect on financial performance of Small and Medium Enterprises in Gusau metropolis of Zamfara state

Null Hypothesis three: performance evaluation practice has no significant effect on financial performance of Small and Medium Enterprises in Gusau metropolis of Zamfara state.

From table 4.2 it shows that performance evaluation has positive significant effect on SMEs financial performance in Gusau at $1 \%$ level of significant. On this note, the researcher therefore not accepting the null hypothesis which says that performance evaluation has no significant effect on financial performance of Small and Medium Enterprises in Gusau metropolis of Zamfara state.

\section{Conclusion}

In view of the analysis and discussion in the preceding chapter, the study concludes as follows:

First, costing practice has positive and statistically significant effect on financial performance of Small and Medium Enterprises in Gusau metropolis of Zamfara state.

Second, budgeting practice has positive and statistically significant effect on financial performance of Small and Medium Enterprises in Gusau metropolis of Zamfara state.

Finally, performance evaluation practice has positive and statistically significant effect on financial performance of Small and Medium Enterprises in Gusau metropolis of Zamfara state.

\section{Recommendations}

Given the above scenarios and the results discussed, the following recommendations become important

i. The owners and managers of Small and Medium Enterprises in Gusau metropolis of Zamfara state should adopt the use of costing practice in their operations as this will help them to know unit cost and it will assist them in fixing price of their product at a profitable rate.

ii. The owners and managers of Small and Medium Enterprises in Gusau metropolis of Zamfara state should adopt the use budgeting practice in their operations as this will help them to compare the actual and budgeted (expenditure and revenue), with this SMEs owners and managers will ensure that they did not spent above the budgeted expenses and to generated revenue beyond the budgeted; this is improve the financial performance of Small and Medium Enterprises in Gusau metropolis of Zamfara state.

iii. The owners and managers of Small and Medium Enterprises in Gusau metropolis of Zamfara state should adopt the use performance evaluation practice in their operations as this will assist them to monitor and control their activities and financial performance from time to time; as this will eventually lead to improvement in their financial performance.

\section{References}

Abdel-Kader, M. \& Luther, R. (2006). Management accounting practices in the British food and drinks industry. British Food Journal, 108, (5), 336-357.

Ahmad, N.N., Sulaiman, M. \& Alwi, N.M. (2003). Are budgets useful? A survey of Malaysian companies. Managerial Auditing Journal, 18( 9), 717-724.

Arithi, N.M. (2001). SMEs: Building Blocks for Economic Growth. Journal of Department of Statistics, Malaysia, 1 . 
Carreta, S. \& Farina, C. (2010). An exploratory investigation of an integrated contingency model of strategic management accounting. Accounting, Organizations and Society, 33, 836-863.

Cassel, Y. (2003). Management accounting practices in the U.S. and Japan: Comparative survey findings and research implications. Journal of International Financial Management and Accounting, 3(1).

Epstein, M. \& Lee, J. (2008). Implementing corporate strategy: from tableaux de bord to balanced scorecards. European Management Journal, 16, 190-203.

Gichaaga, M.J. (2013). An organizational contingencies view of accounting and information systems implementation. Accounting, Organizations and Society, 5, 369-382.

Li, T. \& Yu, J. (2002). Predicting Change in Management Accounting Systems. Journal of management accounting research, 8, 137-150.

Makau, T., Wawire, Y. \& Ofafa, R. (2013). Market competition, management accounting systems and business unit performance. Management Accounting Research, 10, 137-58.

Mbogo R.W. (2011). Organizational Strategy, Structure, and Process. New York: McGraw-Hill.

Mills, F. (2008). A case for researching management accounting in SMEs. Management Accounting: Magazine for Chartered Management Accountants, 76(9), 30.

Nuhu, T., Baird, M. \& Appuhami, R. (2016). Editorial problems, challenges and opportunities: the small business as a setting for management accounting research. Management Accounting Research, 11, 385-390.

Parker, L.D. (2002). Reinventing management accountant. The Chartered Institute of Management Accountant.

Salawu, A.A. (2012). An empirical investigation of the performance consequences of nonfinancial measures. Journal of Management Accounting Research, 15, 193-223.

Smith, M. (2009). Research Methods in Accounting. SAGE Publications.

Sulaiman, M. Ahmad, N.A.N. \& Alwi, N. (2004). Management accounting practices in selected Asian countries. Managerial Auditing Journal, 19(4), 493-508. 342

Ndwiga, A. (2011). The scope of application of management accounting methods in Polish enterprises. Management Accounting Research, 13, 401-418.

Uyar, E. (2010). Changing Role of Management Accounting: Lithuanian Experience Case Studies. ISSN 13922785, Engineering Economics, 5(55).

Van Triest, S. \& Elshahat, M.F. (2007). The use of costing information in Egypt: a research note. Journal of Accounting and Organizational Change, 3(3), 329-343.

Wairegi, Y. (2011). Financing Technology-Bases SMEs in Malaysia: Practices and Problems. 5th SMEs in a Global Economy Conference, August 2nd- 3rd, Senshu University, Kandajimbocho, Tokyo, Japan.

$\mathrm{Wu}$, J., Boateng, A. A \& Drury, C. (2007). An analysis of the adoption, perceived benefits, and expected future emphasis of western management accounting practices in Chinese SOEs and JVs. The International Journal of Accounting, (42), 171-185. 